\title{
Educational technology for people living with HIV: validation study
}

\author{
Tecnologia educacional para pessoas que convivem com HIV: estudo de validação \\ Tecnología educativa para personas que conviven con VIH: estudio de validación
}

\section{Gisele de Brito Brasil', Ivaneide Leal Ataíde Rodrigues', Laura Maria Vidal Nogueira', laci Proença Palmeira' \\ ' Universidade do Estado do Pará, Magalhães Barata School Nursing. Belém, Pará, Brazil.}

\section{How to cite this article:}

Brasil GB, Rodrigues ILA, Nogueira LMV, Palmeira IP. Educational technology for people living with HIV: validation study. Rev Bras Enferm [Internet]. 2018;71(Suppl 4):1657-62. [Thematic Issue: Education and teaching in Nursing] DOI: http://dx.doi.org/10.1590/0034-7167-2017-0824

Submission: 12-13-2017 Approval: 03-09-2018

\section{ABSTRACT}

Objective: to validate an educational technology to support the action of health professionals with people living with HIV. Method: methodological study with data collection using a four-point Likert scale for evaluation by eleven judges and 51 people living with HIV. The data were tabulated, processed, and analyzed by inferential and descriptive statistics, Cronbach's alpha test, and Kruskal-Wallis for reliability and internal consistency analyses. Result: the Cronbach's alpha was 0.974 for judges and 0.694 for the target audience, reliable values. Kruskal-Wallis tested hypotheses $\mathrm{H} 0$ and $\mathrm{H} 1$ with significance of 0.05 . $\mathrm{H} 0$ was accepted with significance of 0.395 for judges and 0.187 for the target audience, demonstrating agreement on the distribution of answers. Judgements with favorable response of at least $70 \%$ were considered relevant, according to the performed tests. Conclusion: the technology presents high reliability and good internal consistency, being deemed appropriate.

Descriptors: Validation Studies; Educational Technology; HIV; Acquired Immunodeficiency Syndrome; Health Education.

\section{RESUMO}

Objetivo: validar tecnologia educacional para subsidiar ação de profissionais de saúde com pessoas convivendo com HIV. Método: estudo metodológico com coleta de dados utilizando escala Likert de quatro pontos para avaliação por onze juízes e 51 pessoas convivendo com HIV. Os dados foram tabulados, processados e analisados por estatística descritiva, inferencial e testes Alfa de Cronbach e Kruskal-Wallis para análise da confiabilidade e consistência interna. Resultado: o Alfa de Cronbach foi 0,974 para juízes e 0,694 para público-alvo, valores confiáveis. O Kruskal-Wallis testou as hipóteses H0 e H1 com significância de 0,05. Aceitou-se H0 com significância de 0,395 para juízes e 0,187 para público-alvo, demonstrando concordância na distribuição das respostas. Consideraram-se relevantes julgamentos com resposta favorável de no mínimo 70\%, conforme testes realizados. Conclusão: a tecnologia apresenta alta confiabilidade e boa consistência interna, sendo considerada adequada. Descritores: Estudos de Validação; Tecnologia Educacional; HIV; Síndrome da Imunodeficiência Adquirida; Educação em Saúde.

\section{RESUMEN}

Objetivo: validar la tecnología educativa para subsidiar acción de profesionales de salud con personas conviviendo con VIH. Método: estudio metodológico con recolección de datos utilizando escala Likert de cuatro puntos para evaluación por once jueces y 51 personas conviviendo con VIH. Los datos fueron tabulados, procesados y analizados por estadística descriptiva, inferencial y pruebas Alfa de Cronbach y Kruskal-Wallis para análisis de la confiabilidad y consistencia interna. Resultado: el Alfa de Cronbach fue 0,974 para jueces y 0,694 para público objetivo, valores confiables. El Kruskal-Wallis probó las hipótesis H0 y H1 con una significación de 0,05. Se aceptó H0 con significancia de 0,395 para jueces y 0,187 para público objetivo, demostrando concordancia en la distribución de las respuestas. Se consideraron pertinentes juicios con respuesta favorable de por lo menos el $70 \%$, según las pruebas realizadas. Conclusión: la tecnología presenta alta confiabilidad y buena consistencia interna, siendo considerada adecuada.

Descriptores: Estudios de Validación; Tecnología Educacional; VIH; Síndrome de Inmunodeficiencia Adquirida; Educación en Salud. 


\section{INTRODUCTION}

In the world's population, according to the United Nations for the Prevention and Control of AIDS, it is estimated that there are 40 million people living with HIV. Throughout its history, the disease has affected various groups of individuals, changing its diversity in the epidemiological distribution pattern and showing different characteristics since its beginning, in the early $1980 \mathrm{~s}^{(1)}$.

Currently, HIV is a continuous and unstable worldwide phenomenon, with different occurrence forms, depending on individual and collective behavioral determinants. As for AIDS, due to its clinical manifestations in latter stages, it stands out among the emerging infectious diseases due to its large amplitude and damage extent ${ }^{(2)}$.

In Brazil, 882,810 cases of AIDS were recorded between 1980 and June 2017, with a yearly average of 40 thousand new cases in the last five years. Between 2012 and 2016, the North region presented an average of 4.2 thousand cases per year. It is worth noting that the states of Amapá and Pará doubled their detection rates between 2006 and $2016^{(3)}$.

Regarding mortality from AIDS in the country, records show that since the beginning of the epidemic until December 31, 2016, 316,088 deaths were reported having HIV/AIDS as root cause. In the North and Northeast regions of Brazil, the coefficients suffered increases of $7.6 \%$ and $2.3 \%$ in the same period, following the trend of growth in these regions over the past 10 years ${ }^{(3)}$.

The person who lives with the disease suffers great impact on the biological, personal, and social contexts, which leads to changes that require management and re-adaptation in routine activities. Due to the expansion of HIV, it is necessary to search for information and orientation strategies directed to people living with HIV, as well as to the professionals who accompany them in the everyday life of health units. To mediate actions in health, it is possible to count on educational technologies, tools that enable reflections resulting from the experiences of those involved in the process of preparation, planning, and execution of these products. After this production, validation is required to assure the reliability of the contents and form of the technology ${ }^{(4)}$.

Validation is defined as the truth or as an aspect that moves away from it when conducting investigations involving new tools or instruments used by other research, with reliability and validity being required, and thus reflecting the theoretical concepts being tested. The conclusions drawn from the study must be coherent, otherwise the shall be invalid and shall not promote the development of these tools or instruments. Validation comes from the knowledge on the researcher's technique in accordance with the judges' conclusions when relating the results of the study with the subject in focus ${ }^{(5)}$.

Considering that printed educational technologies are important tools for information and awareness of various social groups, we understand that it is relevant to validate the educational technology as a health education strategy at the local context, thus contributing to broaden access to information regarding $\mathrm{HIV}^{(6)}$.

The booklet entitled "Tips for living well" was developed according to methodological criteria recommended in the literature and with scientific rigor, aspects that contributed to the quality of the material, taking into account the needs of the target audience, in this case, people living with HIV. In this sense, the need and relevance of this type of study to guide professionals who wish to or are already developing activities aimed at health education are justified ${ }^{(7)}$.

Therefore, we defined the following question to guide this study: is the educational technology developed a valid instrument to be used by health professionals who care for people living with HIV?

\section{OBJECTIVE}

To validate an educational technology to support the action of health professionals with people living with HIV.

\section{METHOD}

\section{Ethical aspects}

The study followed the precepts of the National Health Council Resolution No. 466/2012 and was approved by the Research Ethics Committee of the Nursing School of the State University of Pará. Health professionals and people living with HIV participated in the study.

The professionals were contacted in their workplaces or by e-mail, being informed about the study and invited to participate. Those who agreed were given an envelope containing an informed consent form, an invitation letter, a printed version of the booklet to be validated, and the Likert scale adapted to be analyzed by the judges. At the time of delivery of the envelope, the process of validation was explained, the consent form was read, and delivery was arranged.

The target audience was chosen for convenience, contacted at the waiting room according to attendance on the reference health unit chosen as the study location and invited to participate. Those who accepted were led to a room on the unit, where the consent form was read, and the Likert scale was applied by the researcher, with content relevant to its evaluation. Both the judges and the target audience signed the informed consent form, formalizing their consent.

\section{Study design, location, and period}

This is a descriptive methodology research with quantitative approach, carried out in a reference health unit for treatment of HIV in Belém, state of Pará, Brazil.

The educational technology validated in this study was the product of the first step of a project approved by Public Notice No. 14/2013-track B. This step was developed in conjunction with the health care professionals operating in the reference unit, by the focal group technique. Four meetings were carried out on the premises of the unit, from April to October 2015, with an average participation of six health care professionals graduated or technicians.

The discussions in the group were based on a script-guide with questions related to the presentation and content of technology designed for people living with HIV. The recorded material was transcribed and subjected to content analysis( ${ }^{(8)}$, which allowed the identification of the themes that would make up the technology. 
After defining the content, the group opted for the construction of a printed technology using accessible language and illustrations to facilitate viewing. The themes highlighted by the professionals concerned specific issues about HIV, aspects related to everyday life, and formal information, such as personal identification documents and updated address.

A brochure booklet was then produced, called "Tips for living well", composed by the cover and 14 pages, with a standard formatting size of $25 \mathrm{~cm} \times 15 \mathrm{~cm}$. Each page was designed with up to four illustrations, totaling nine, and textual development in ten topics.

The validation process was carried out in three steps. In the first, in October 2016, the technology was evaluated by expert judges. In the second stage, carried out from January to February 2017, the booklet was evaluated by the target audience, in this case, people living with HIV. In the third step, the data obtained were organized and analyzed quantitatively by means of statistical procedures.

\section{Sample: inclusion criteria}

The technology was evaluated by eleven expert judges, chosen by indication of the professionals who worked in the reference health unit and participated in the development of the technology. That number accounted for approximately $50 \%$ of professionals working in the period of data collection, according to the methodology used in other studies ${ }^{(9)}$. In this selection, in addition to the indication, the judges' experience with HIV and their affinity with the objectives of the research were also taken into account. For the purposes of this study, we considered as expert health professionals, specialized or not, who have already been working with diagnosis, treatment, and control of HIV for at least five years. These professionals worked in different reference health units, to avoid conflicts of interest. The professionals who were not in full exercise of their activities during the period of data collection were excluded from the study.

We sought professionals with expertise in the regional level, since the development of the booklet considered the cultural and geographic peculiarities of the North region, which is different from other Brazilian regions. We took into account that the educational guidelines drawn up at the national level are not always suited to regional peculiarities, which is often considered a problem by professionals when developing educational approaches and sharing information with users.

The target audience consisted of 51 people living with HIV, chosen for convenience, which represented $20 \%$ of eligible participants (all that were scheduled for the period of data collection, approximately 250).

\section{Study protocol}

For both the judges and the target audience, the Likert scale was used as data collection instrument, which is a classification technique with several items that express a positive or negative point of view about a particular analyzed topic ${ }^{(10)}$. Both groups made their assessment by filling out the scale and choosing the best rating for the answer, according to the items: completely adequate; adequate; partially adequate; and inadequate, on a scale of values that ranged from 1 (completely adequate) to 4 (inadequate), informing their degree of agreement or disagreement to each item to be evaluated.

The scale featured different aspects for the two groups to guide their analysis: to the judges, it was composed of 22 items and four blocks - objectives, structure, presentation, and relevance. For the audience, there were 15 items and five blocks - objectives, organization, writing style, appearance, and motivation. This last block was included only in the scale for the target audience.

\section{Analysis of the results}

The collected data were tabulated, interpreted, processed, and analyzed through descriptive and inferential statistics, using processing resources in Microsoft Excel and Statistic Package for Social Sciences (SPSS) version 22.0, all in the Windows 7 environment. The statistical tests Cronbach's alpha and KruskalWallis were also carried out.

In addition to the statistical analysis done in this study, we also considered the opinion of expert judges and the audience, who expressed partial agreement with some of the factors presented and made suggestions based on their own experiences and knowledge, which was potentially relevant to the study. The understanding of each one, following commentaries and suggestions, were accepted, synthesized, and implemented in the technology.

\section{RESULTS}

The first sample was composed of eleven judges aged averagely between 35 and 44 years (5/45,45\%), all women. Regarding professional category, there were three nurses $(3 / 27,27 \%)$, two speech language therapists $(2 / 18,18 \%), 2$ physicians $(2 / 18,18 \%)$, one physical therapist $(1 / 9,09 \%)$, one occupational therapist $(1 / 9,09 \%)$, one social worker $(1 / 9,09 \%)$, and one nutritionist $(1 / 9,09 \%)$. As for the time of training, participants had up to fifteen years of training.

The second sample, the target audience, was composed by 51 people living with HIV. The average age was between 50 and 59 years old $(18 / 35,29 \%)$. The majority were female $(29 / 56,86 \%)$ and $18 \%$ had graduated high school (21/41).

Cronbach's alpha was used to analyze the internal consistency reliability of the instrument. For the judges, the value obtained was 0.974 , being considered reliable, since it can vary from 0 to 1 , and the closer to 1 , the greater the reliability of the instrument. The ideal value should be between 0.7 and $1.0^{(11)}$ (Table 1).

For the target audience, the value obtained, 0.694, was also considered reliable (Table 2).

Table 1 - Internal consistency coefficient of the instrument applied to expert judges, Belém, Pará, Brazil, 2017

\begin{tabular}{ccc}
\hline Cronbach's Alpha & $\begin{array}{c}\text { Cronbach's Alpha based } \\
\text { on standardized items }\end{array}$ & $\begin{array}{c}\mathbf{n} \\
\text { (items) }\end{array}$ \\
\hline 0.974 & 0.976 & 22 \\
\hline
\end{tabular}


Table 2 - Internal consistency coefficient of the instrument applied to the target audience, Belém, Pará, Brazil, 2017

\begin{tabular}{ccc}
\hline Cronbach's Alpha & $\begin{array}{c}\text { Cronbach's Alpha based } \\
\text { on standardized items }\end{array}$ & $\begin{array}{c}\mathbf{n} \\
\text { (items) }\end{array}$ \\
\hline 0.694 & 0.772 & 15 \\
\hline
\end{tabular}

The Kruskal-Wallis test was used to verify whether the independent samples came from populations with the same averages or significantly different averages. This test allows to verify if the answers converge to the same average score ${ }^{(12)}$.

For the expert judges, the test statistics $(\mathrm{H})$ showed a $\mathrm{p}$-value equal to 0.391 (Table 3), and of 0.187 for the target audience (Table 4). As these values are greater than $\alpha=0.05$, the decision is to accept $\mathrm{H}_{0}$. Therefore, there is no difference in the scores presented by the expert judges and by the target audience, which is an indicator of high degree of suitability between the participants around the most frequent answers, which were "completely adequate" and "adequate".

Table 3 - Hypothesis test (Kruskal-Wallis of independent samples), Belém, Pará, Brazil, 2017

\begin{tabular}{|c|c|c|c|}
\hline Null hypothesis & Test & Significance & Decision \\
\hline $\begin{array}{l}\text { The distribution of } \\
\text { answers is the same } \\
\text { among respondents } \\
\text { (expert judges). }\end{array}$ & $\begin{array}{l}\text { Kruskal- } \\
\text { Wallis Test for } \\
\text { independent } \\
\text { samples }\end{array}$ & 0.391 & $\begin{array}{l}\text { Retain } \\
\text { the null } \\
\text { hypothesis. }\end{array}$ \\
\hline
\end{tabular}

Note: Asymptotic significances are shown. The significance level was 0.05 (p-value).

Table 4 - Hypothesis test (Kruskal-Wallis of independent samples), Belém, Pará, Brazil, 2017

\begin{tabular}{|c|c|c|c|}
\hline Null hypothesis & Test & Significance & Decision \\
\hline $\begin{array}{l}\text { The distribution of } \\
\text { answers is the same } \\
\text { among respondents } \\
\text { (target audience). }\end{array}$ & $\begin{array}{l}\text { Kruskal- } \\
\text { Wallis Test for } \\
\text { independent } \\
\text { samples }\end{array}$ & 0.187 & $\begin{array}{c}\text { Retain } \\
\text { the null } \\
\text { hypothesis }\end{array}$ \\
\hline
\end{tabular}

Note: Asymptotic significances are shown. The significance level was 0.05 (p-value).

For the validation, we considered relevant judgements with favorable answer percentage of at least $70 \%$, based on the statistical tests performed. This index of agreement was based on other validation studies ${ }^{(12-13)}$.

\section{DISCUSSION}

Health education is a primordial element to achieve the goals of health promotion, since it raises the awareness of individuals, transforming their life habits to improve self-care, assisting in the right to choose how to act in the situations imposed by the new everyday life of living with the disease. In this study, among the health professionals involved in the practice of educational actions, nurses have taken on an important role, as they are often ahead of the educational activities and always seek new opportunities to mediate these actions ${ }^{(14)}$.

This is the case regarding chronic diseases such as HIV, in which nursing acts in therapeutic enhancement, creating a link and promoting, by means of discussions, a unique care. They take the biopsychosocial into account in the continuous educational process, for both patients and their families, which results in better adherence to treatment and acceptability of the condition ${ }^{(15)}$.

As recommended ${ }^{(16)}$, the booklet was validated according to scientific criteria, considering reliability as an important indicator of quality, employing the congruence of answers and understanding that the content's consistency comes from concurrence among evaluators, in this case, the judges and the target audience. Another factor we considered was the validity of the instrument as to the clarity of the items, ease of reading, understanding, and form of presentation. This aspect concerns the evaluation of those who shall use the instrument, the target audience. Although it is very relevant, this aspect should not be used in isolation for validation ${ }^{(17)}$.

Considering, in the process of validation, the analysis through Cronbach's alpha test, for the expert judges and the target audience, the results of 0.974 and 0.694 , respectively, were deemed reliable, due to their proximity to the value 1 . Given this context, studies highlight the importance of reliability as to the uniformity of each item of a scale, measured by the consistency of the evaluators' responses. These findings corroborate the results of this research ${ }^{(17-19)}$.

A study carried out to validate a surgical safety checklist emphasized the reliability of a validated instrument as something that contributes with the professional in all areas of knowledge, allowing the recognition of avoidable risk situations, educational actions, and valuing the management to whom it is intended. Thus, reliability reflects the credibility of the validated instrument ${ }^{(20)}$.

Still on the degree of adequacy around most frequent answers, Kruskal-Wallis tested hypotheses $\mathrm{H}_{0}$ and $\mathrm{H}_{1}$ with a significance level of $95 \%$. As a result of the research, we accepted $\mathrm{H}_{0}$ with significance of 0.391 and 0.187 , demonstrating agreement in the distribution between the answers of judges and audience. These values have been already applied to consider valid answers in studies that dealt with quality of life in the workplace of the nursing staff of public health institutions ${ }^{(21)}$.

Studies highlight the importance of procedures to assess the adequacy of the items that compose the scale for validation. Thus, the methodological rigor of the statistical tests, such as Kruskal-Wallis, are important to confirm the validation of an instrument, showing the need to perform several tests to increase the credibility and reliability of the developed material ${ }^{(12)}$, which was strictly followed in this study.

The final version of the booklet brought essential information, in addition to containing illustrations consistent with the text, facilitating the communication and understanding of those who shall use it. In this sense, the participation of experts and representatives of the target audience can raise the credibility and acceptance of the material, as found in this research ${ }^{(22)}$.

\section{Study limitations}

We understand as a limitation of this study the existence, at the time of its development and analysis, of little research on the topic, which limited the discussion and dialogue. Thus, its disclosure may help to reduce this gap. 


\section{Contributions to the fields of health and nursing}

We understand that, when developing and validating an educational technology for people living with HIV, it is possible to contribute to the field of health in general and nursing, which acts strongly in the area of health education, because we are offering a qualified instrument to be used by both professionals, in their everyday activities, and the target audience, favoring access to themes, guidelines, and suggestions that can facilitate everyday life in coexistence with the pathology and in transmission prevention.

\section{CONCLUSION}

The study achieved its aim to demonstrate, by means of validation, that the booklet called "Tips for living well" has high reliability and good internal consistency, being considered adequate, according to the assessment of the judges and target audience, to be used by health professionals in the management of people living with HIV. The participation of these two groups in the validation process of the booklet allowed us to finalize a material that is easy to read, has accessible language, and is very useful in the fulfillment of its primary purpose, which is to mediate the communication between professionals and users at appointments.

The development of this research allowed us to present the validation process of an educational technology based on the relationship between the needs identified by health professionals in the care of people living with HIV and the scientific knowledge on the subject, which, besides facilitating, in practical terms, the educative actions in health and the everyday life of the people affected, can also help to subsidize new studies.

\section{REFERENCES}

1. Maliskai ICA, Padilha MICS, Andrade SR. AIDS and early responses to the epidemic: contributions from health professionals. Rev Enferm UERJ[Internet]. 2015[cited 2017 Aug 25];23(1):15-20. Available from: http://www.e-publicacoes.uerj.br/index.php/ enfermagemuerj/article/view/4295/18116

2. Orlandi FS, Praça NS. The hope of women with HIV/AIDS: evaluation using the herth scale. Texto Contexto Enferm[Internet]. 2012[cited 2017 Jun 30];22(1):141-8. Available from: http://www.scielo.br/pdf/tce/v22n1/17.pdf

3. Brasil. Ministério da Saúde. Secretaria de vigilância em saúde. Departamento de DST, Hepatites Virais e AIDS. Boletim epidemiológico HIV Aids 2017 [Internet]. Brasília: Ministério da Saúde; 2017 [cited 2017 Aug 21]. Available from: http://www.aids.gov.br/pt-br/ pub/2017/boletim-epidemiologico-hivaids-2017

4. Nietsche EA, Lima MGR, Rodrigues MGS, Teixeira JA, Oliveira BNB, Motta CA. [Innovative technologies of nursing care]. Rev Enferm UFSM[Internet]. 2012[cited 2017 Jun 30];2(1):182-9. Available from: https://periodicos.ufsm.br/reufsm/article/view/3591 Portuguese

5. Guimarães PV, Haddad MCL, Martins EAP. Instrument validation for assessing critically ill patients on mechanical ventilation according to the ABCDE. Rev Eletr Enferm [Internet]. 2015[cited 2017 Jun 30];17(1):43-50. Available from: https://www.fen.ufg. br/revista/v17/n1/pdf/v17n1a05.pdf

6. Benevides JL, Coutinho JFV, Pascoal LC, Joventino ES, Martins MC, Gubert FA, et al. Development and validation of educational technology for venous ulcer care. Rev Esc Enferm USP [Internet]. 2016 [cited 2017 Jun 20];50(2):306-12. Available from: http:// www.scielo.br/pdf/reeusp/v50n2/0080-6234-reeusp-50-02-0309.pdf

7. Ilha S, Santos SSC, Backes DS, Barros EJL, Pelzer MT, Oliveira AMN. Educational and care-related (geronto) technology in alzheimer's disease and in supporting the elderly/family: perspective of teachers and students. Esc Anna Nery Rev Enferm [Internet]. 2017[cited 2017 Sep 05];21(2):1-8. Available from: http://www.scielo.br/pdf/ean/v21n2/en_1414-8145-ean-21-02-e20170039.pdf

8. Bardin L. Análise de conteúdo. 4ª ed. Lisboa: Edições 70; 2011.

9. Pasquali L. Instrumentação psicológica: fundamentos e práticas. Porto Alegre: Artmed; 2010.

10. Moreira APA, Sabóia VM, Camacho ACLF, Daher DV, Teixeira E. [Educational game of medication administration: a validation study]. Rev Bras Enferm [Internet]. 2014 [cited 2017 Aug 17];67(4):528-34. Available from: http://www.scielo.br/pdf/reben/v67n4/00347167-reben-67-04-0528.pdf Portuguese

11. Lins SMSB, Leite JL, Godoy S, Fuly PSC, Araujo STC, Silva IR. Validation of the adherence questionnaire for Brazilian chronic kidney disease patients under hemodialysis. Rev Bras Enferm [Internet]. 2017[cited 2017 Jun 15];70(3):558-65. Available from: http://www.scielo.br/pdf/reben/v70n3/0034-7167-reben-70-03-0558.pdf

12. Martins PR, Fonseca LF, Rossetto EG, Mai LD. Developing and validating the Perioperative Thirst Discomfort Scale. Rev Esc Enferm USP [Internet]. 2017[cited 2017 Aug 20];51:e03240. Available from: http://www.scielo.br/pdf/reeusp/v51/1980-220X-reeusp51-e03240.pdf

13. Silva ATM, Mantovani MF, Godoy S, Kalinke LP, Ulbrich EM. [Predictive scale of hypertension complications: content and appearance validity]. Rev Min Enferm [Internet]. 2017 [cited 2017 Jun 19];21:e1007. Available from: http://www.reme.org.br/ artigo/detalhes/1143 Portuguese

14. Nietsche EA, Teixeira E, Medeiros HP. Organizadores. Tecnologias cuidativo-educacionais: uma possibilidade para o empoderamento do enfermeiro (a). Porto Alegre: Moriá; 2014

15. Pedreira RB, Rocha SV, Santos CA, Vasconcelos LRC, Reis MC. Content validity of the geriatric health assessment instrument. Einstein 
[Internet]. 2016 [cited 2017 Jul 06];14(2):158-77. Available from: http://www.scielo.br/pdf/eins/v14n2/1679-4508-eins-14-2-0158.pdf

16. Teixeira E, Martins TDR, Miranda PO, Cabral BG, Silva BAC, Rodrigues LSR. [Educational technology on postpartum care: development and validation]. Rev Baiana Enferm [Internet]. 2016 [cited 2017 Aug 20];30(2):1-10. Available from: https://portalseer. ufba.br/index.php/enfermagem/article/view/15358/pdf_53 Portuguese

17. Colli M, Zani AV. [Validation of a nursing discharge plan for pregnant and high-risk puerperal women]. Rev Min Enferm [Internet]. 2016[cited 2017 Jul 04];20(1):1-7. Available from: https://www.reme.org.br/exportar-pdf/1068/e934.pdf Portuguese

18. Dini AP, Alves DFS, Oliveira HC, Guirardello EB. Validity and reliability of a pediatric patient classification instrument. Rev LatinoAm Enfermagem [Internet]. 2014 [cited 2017 Jul 17];22(4):598-603. Available from: http://www.scielo.br/pdf/rlae/v22n4/01041169-rlae-22-04-00598.pdf

19. Roncada C, Dias CP, Goecks S, Cidade SEF, Pitrez PMC. Usefulness of the WHOQOL-BREF questionnaire in assessing the quality of life of parents of children with asthma. Rev Paul Pediatr [Internet]. 2015[cited 2017 Jul 20];33(3):267-73. Available from: http:// www.scielo.br/pdf/rpp/v33n3/en_0103-0582-rpp-33-03-0267.pdf

20. Jansen AC, Marziale MHP, Santos CB, Dantas RAS, Santos DMSS. Validation of the Comply with Post-Exposure Management Among Health Care Workers instrument for Brazil. Rev Esc Enferm USP [Internet]. 2016[cited 2017 Apr 10];50(6):971-9. Available from: http://www.scielo.br/pdf/reeusp/v50n6/0080-6234-reeusp-50-06-00973.pdf

21. Alpendre FT, Cruz EDA, Dyniewicz AM, Mantovani MF, Silva AEBC, Santos G. Validation of pre and postoperative checklists. Rev Latino-Am Enfermagem[Internet]. 2017[cited 2017 Jul 20];25:e2907. Available from: http://www.scielo.br/pdf/rlae/v25/01041169-rlae-25-e2907.pdf

22. Zavala MOQ, Klijn TP, Carrillo KLS. Quality of life in the workplace for nursing staff at public healthcare institutions. Rev LatinoAm Enfermagem[Internet]. 2016[cited 2017 Jul 20];24:e2713. Available from: http://www.scielo.br/pdf/rlae/v24/0104-1169rlae-24-02713.pdf 